\title{
Dalhousie Journal of Legal Studies
}

$1-1-2004$

\section{International Law from Below: Development, Social Movements and Third World Resistance}

Graham Reynolds

Follow this and additional works at: https://digitalcommons.schulichlaw.dal.ca/djls

(c) (i) $(9)$

This work is licensed under a Creative Commons Attribution-Noncommercial-No Derivative Works 3.0 License.

\section{Recommended Citation}

Graham Reynolds, "International Law from Below: Development, Social Movements and Third World Resistance" (2004) 13 Dal J Leg Stud 273.

This Book Review is brought to you for free and open access by the Journals at Schulich Law Scholars. It has been accepted for inclusion in Dalhousie Journal of Legal Studies by an authorized editor of Schulich Law Scholars. For more information, please contact hannah.steeves@dal.ca. 


\section{International Law from Below: Development, Social Movements and Third World Resistance}

Balakrishnan Rajagopal

New York: Cambridge University Press, 2003 (360 pp)

Reviewed by Graham Reynolds ${ }^{\dagger}$

In the South Indian states of Tamil Nadu, Karnataka, and Andhra Pradesh, the Working Women's Forum, India's largest women's social movement, struggles against patriarchy, culture, and politics. ${ }^{1}$ In a similar manner, social movements such as the Zapatistas in Mexico, the urban squatters movement in Brazil, and the Venezuelan Ecology Movement challenge traditional notions of development and modernization. ${ }^{2}$ Throughout the $20^{\text {th }}$ century, social movements have fought to affect legal change on both domestic and international planes. However, their story has been excluded from the narrative of international law. Social movements have been rendered invisible in international legal discourse.

In International Law from Below, ${ }^{3}$ Balakrishnan Rajagopal fights against this exclusion by engaging in a fundamental rewriting of international law. Through the course of his work, Rajagopal writes back, ${ }^{4}$ adding a new narrative to the text of legal discourse by revealing the role social movements have played in shaping international law. As well, Rajagopal uses social movements to develop an alternative theory of resistance against traditional discourses of development, moderniza-

\footnotetext{
$\dagger$ Graham Reynolds graduated from the University of Manitoba in 2002 with a B.A. in English. $\mathrm{He}$ is a second year law student at Dalhousie University.

${ }^{1}$ Balakrishnan Rajagopal, International Law from Below (New York: Cambridge University Press, 2003) at 272.

${ }^{2}$ Rajagopal, supra note 1 at 250.

${ }^{3}$ Rajagopal, supra note 1.

${ }^{4}$ An allusion to the postcolonial text The Empire Writes Back. Bill Ashcroft, Gareth Griffiths \& Helen Tiffin, The Empire Writes Back: Theory and Practice in Post-Colonial Literatures (New York: Routledge, 1989).
} 
tion, and human rights. His book is the first to critique international law from the perspective of Third World social movements. ${ }^{5}$

Such an analysis is timely. Protests in Seattle and Quebec City, among many others, have demonstrated global society's growing dissatisfaction with development, modernization, and the monolithic state. A fundamental shift to a social movement perspective, as advocated by Rajagopal, is necessary if international law is to maintain its relevance in the $21^{\text {st }}$ century.

International Law from Below builds on the insights of postcolonialism, poststructuralism, postmodernism, critical race theory, critical development theory, and critical Third World Scholarship. ${ }^{6}$ Rajagopal cites the works of Michel Foucault, Franz Fanton, Antonio Gramsci, and Partha Chatterjee as particular inspirations for his theory of resistance. In building his internal critique, Rajagopal makes extensive use of discourse analysis, deconstructing modern international law to reveal its hidden assumptions. Though a general understanding of literary and legal theory is helpful in grasping the nuances and subtleties of Rajagopal's argument, a theoretical foundation is not necessary to appreciate the ground-breaking nature of his critique.

Rajagopal's work is structured in four parts. Part I introduces the question of theorizing resistance as an analytical category in international law and analyses 'development' in the post-World War II years. Part II explores four critical moments of international institutional expansion in the context of development and resistance. Part III has two main goals: to critique human rights discourse as the sole approved discourse of resistance, and to explore the theoretical challenges social movements pose for international law. Part IV, the Epilogue, discusses future challenges for social movements in international law. ${ }^{7}$

In Part I, Rajagopal charts the evolution of development ideology in international law, ultimately rooting development discourse in colonialism. After WWII, as colonialism crumbled, the colonizer-colonized relationship began to be replaced by the developed-underdeveloped relationship. ${ }^{8}$ However, embedded deep within the ideology of develop-

\footnotetext{
${ }^{5}$ Rajagopal, supra note 1 at 3.

${ }^{6}$ Rajagopal, supra note 1 at 3.

${ }^{7}$ Rajagopal, supra note 1 at 4.

${ }^{8}$ Rajagopal, supra note 1 at 25.
} 
ment is the ideology of colonialism, replete with ideas of Western modernity, progress, and superiority.

Rajagopal discusses the institutionalization of development ideology (and, by extension, colonialism) through international institutions and international law in Part II of his work. As he notes, international law and institutions evolved rapidly during the same period as the emergence of development discourse, growing to govern the relationship between the West and the rest of the world. ${ }^{9}$ Third World resistance, specifically social movement resistance, played a critical role in shaping and guiding the evolution of international law and institutions. However, in traditional legal narratives, this complex dialectic is reduced to a single entity, the institution. The influence of social movements is overlooked, and the voice of social movement resistance is made silent.

Part III of International Law from Below consists of a discursive analysis of modern human rights. Rajagopal notes that for many in the West, "human rights discourse has emerged as the sole language of resistance to oppression and emancipation in the Third World." ${ }^{10}$ Resistance falling outside of the discursive walls of human rights is excluded from the text of international law, rendered invisible. Rajagopal reveals the risks inherent in relying entirely on modern human rights as "the next grand discourse of emancipation and liberation," 11 exposing both the colonial origins of human rights discourse and the limitations of modern human rights in protecting the rights of citizens in Third World societies.

However, Rajagopal does not advocate a complete departure from public action in the protection of human rights. He notes that some state action is necessary to protect the basic rights of an individual. What Rajagopal objects to is the role of the traditional state as the sole defender of the rights of individuals and communities. Social movements have the potential to act as alternative defenders whose actions will achieve more than the self-perpetuation and replication of the state and the international institution. Instead, by presenting alternative forms of rights and resistance that cannot be defined within the standard paradigms of

\footnotetext{
${ }^{9}$ Rajagopal, supra note 1 at 40.

${ }^{10}$ Rajagopal, supra note 1 at 172 .

${ }^{11}$ Rajagopal, supra note 1 at 173.
} 
Western modernity, social movements help decentre the state, challenge international law, and give voice to a multiplicity of perspectives.

In the same way in which Rajagopal notes that the "arrival" of social movements in international law does not condemn the state to an existence as an insignificant actor, he states in Part IV that the new social movement perspective does not lead to the dismissal of international institutions as important actors in international law. On the contrary, he notes that:

[B]y being closely interwoven with 'local' social movements that generate pressures for change, international institutions may yet have the potential to contribute to that change. ${ }^{12}$

Given Rajagopal's earlier critique of international institutions as entities which continue to help legitimize colonization in the Third World, the reader must question his return to institutions as part of the solution. The risks in doing so are apparent: until the traditional Western frameworks of international institutions are themselves altered, the structures of colonization will continue to replicate, silencing the multiplicity of voices within the Third World and upholding the monolithic dominance of the state. However, the author himself anticipates the risk of his return to institutions, posing the following question to his readers:

\begin{abstract}
What should one, then, make of social movements during this moment? Do they present an opportunity for a creative way to build a local-global nexus that somehow transcends the imperialistic purposes of 'globobabble', or will they prove to be the Trojan horses that would reinvite the colonizer inside Third World societies? I don't really know. I would only argue that a blind opposition to either approach is likely to be a major folly. ${ }^{13}$
\end{abstract}

Rajagopal's uncertainty regarding the ability of social movements to effect true change in the near future must not detract from the strength of his work. Firstly, it is not in the nature of discourse analysis itself to provide concrete solutions to specific issues. Rather, discourse analysis seeks to uncover the assumptions in a given discourse, unearthing its hidden motivations and foundational beliefs. Rajagopal accomplishes this, revealing both the interaction between colonization and develop-

\footnotetext{
${ }^{12}$ Rajagopal, supra note 1 at 294-295.

${ }^{13}$ Rajagopal, supra note 1 at 269.
} 
ment/modernism/human rights in international law, and the influence of social movement resistance on this interaction.

Secondly, Rajagopal set out to write the influence of social movements into the text of the master legal narrative. This goal is historical. Thus, the crucial aspect of his work is found not in his vision for the future, but in his vision of the past. Essentially, Rajagopal, in using discourse analysis to critique modern international law from a social movement perspective, is rewriting the history of international law. Such a rewriting is essential to continue the process of displacing international law from Western ideals, eurocentrism, and imperialism. As Rajagopal notes:

[T]he history of international law has been written so far from the perspective of states, stressing the role played by institutions and leading western scholars and leaders, and guided by a concern for the...global cosmopolitan class. ${ }^{14}$

In inscribing a history for Third World society in International Law from Below, Rajagopal writes from the perspective of social movements, stressing the role played by local groups, communities and individuals, and guided by a concern for the repressed, the oppressed, and the excluded. He writes a history for the invisible, for the voiceless. In writing their text into the narrative of international law, he gives them body and voice. He creates space for resistance, giving social movements a presence from which to advance alternative theories of development, modernization, and governance. Rajagopal does so in the hope that international law can be transformed from a "law of domination to one of resistance in the aid of marginal communities and peoples," 15 from a unitary, monolithic entity that risks slipping further and further from contemporary relevancy to a plurality of perspectives actively shaping 